Байкальский государственный университет, 2. Иркутск, Российская Федеращия

О. Н. Пензина

Байкальский государственный университет, 2. Иркутск, Российская Федерация

\title{
О ПРИМЕНЕНИИ ПРОФЕССИОНАЛЬНЫХ СТАНДАРТОВ ПРИ ПРОЕКТИРОВАНИИ ОБРАЗОВАТЕЛЬНЫХ ПРОГРАММ В ВУЗЕ
}

\begin{abstract}
АннотАция. Анализируется проблема применения профессиональных стандартов при проектировании основных профессиональных образовательных программ в вузах при переходе на Федеральные государственные образовательные стандарты нового поколения (ФГОС ВО 3++). Раскрываются основные проблемы, возникающие в данном процессе, в том числе терминологическая рассогласованность ФГОС и профессиональных стандартов (ПС) и необходимость их сопряжения, неполный охват профессиональными стандартами различных областей профессиональной деятельности, быстрое устаревание утвержденных ПС по ряду видов профессиональной деятельности и ряд других. На примере Байкальского государственного университета проведен анализ наличия профессиональных стандартов, соответствующих профессиональной деятельности выпускников по реализуемым образовательным программам, а также принятых ФГОС ВО $3++$, их проектов и примерных основных образовательных программ. Выявлены недостатки проектов ФГОС ВО 3++, а также полное отсутствие примерных основных образовательных программ. Определены риски образовательных организаций при разработке основных профессиональных образовательных программ в соответствии с профессиональными стандартами, в том числе при отсутствии примерных основных образовательных программ.

кЛЮчЕВЫЕ слОВА. Профессиональный стандарт; высшее образование; федеральный государственный образовательный стандарт; образовательная программа.

ИНФОРМАЦИЯ О СТАТЬЕ. Дата поступления 31 января 2018 г.; дата принятия к печати 19 марта 2018 г.; дата онлайн-размещения 09 апреля 2018 г.
\end{abstract}

T. G. Ozernikova Baikal State University, Irkutsk, Russian Federation

O. N. Penzina

Baikal State University, Irkutsk, Russian Federation

\section{THE SCORING SYSTEM OF ASSESSING INDUSTRIAL POTENTIAL OF AN ENTERPRISE}

\begin{abstract}
The article analyses the problem of professional standard applications in developing the basic university professional educational programs in the transition to the Federal State Educational Standards of a new generation (FSES HE $3++$ ). The article reveals the main problems that arise in this process, including the terminological disagreement between the FSES and the professional standards (PS) and the need for their integration, the incomplete coverage of the professional standards of various areas of professional activity, the rapid obsolescence of the approved PS for a number of the professional activities and a number of others. As illustrated by Baikal State University, the article analyses the availability of professional standards that are relevant to
\end{abstract}

\section{Baikal Research Journal}


the professional activities of the graduates according to the educational programs to be implemented, as well as the adopted FSES HE $3++$, their projects and approximate basic educational programs. The shortcomings of FSES HE $3++$ projects are revealed, as well as the complete absence of exemplary basic educational programs. The article identifies the risks of educational organizations in developing the main professional educational programs in accordance with the professional standards, considering the absence of exemplary basic educational programs.

KEYWORDS. Professional standard; higher education; federal state educational standard; educational program.

ARTICLE INFO. Received January 31, 2018; accepted March 19, 2018; available online April 09, 2018.

Трансформация системы квалификаций на основе разработки и внедрения профессиональных стандартов в Российской Федерации является закономерным процессом, соответствующим тенденциям развития экономики и изменениям сферы занятости. В настоящее время разработаны 1046 профессиональных стандартов. По своему функциональному назначению профессиональный стандарт служит отражением нормативных требований к уровню квалификации рабочей силы в различных профессиональных сферах [1, с. 69-70]. Цели применения профессиональных стандартов (ПС) определены Национальным советом по развитию квалификаций при президенте РФ:

1. ПС применяются работодателями при формировании кадровой политики и в управлении персоналом, при организации обучения и аттестации работников, разработке должностных инструкций, тарификации работ, присвоении тарифных разрядов работникам и установлении систем оплаты труда с учетом особенностей организации производства, труда и управления.

2. ПС применяются образовательными организациями профессионального образования при разработке профессиональных образовательных программ.

3. ПС применяются при разработке в установленном порядке федеральных государственных образовательных стандартов профессионального образования.

Переход образовательных организаций профессионального образования к федеральным государственным образовательным стандартам нового поколения, разрабатываемых с учетом требований профессиональных стандартов (ФГОС ВО $3++)$, впервые предоставляет возможность прямой интеграции результатов обучения и требований работодателей. В то же время, этот переход сопряжен с рядом проблем, вызвавших в научном и образовательном сообществе бурные дискуссии.

Тенденция ориентации ФГОС на требования профессиональных стандартов вызвала у многих исследований обоснованные опасения. Так, высказывается и аргументируется точка зрения о том, что попытки подчинить образовательные стандарты требованиям профессионального сообщества работодателей, использующего для этого в качестве инструмента профессиональные стандарты, противоречат основной идее многоуровневой структуры основных образовательных программ высшей школы, основой которых является универсальность, фундаментальность и научность приобретаемых студентами знаний, их университетский характер. Профессиональные стандарты имеют практическую направленность, отражают требования бизнеса, в них отсутствуют требования к общенаучной и фундаментальной подготовке выпускников [2, с. 31-36]. Отмечается отсутствие в профстандартах научной составляющей, которая необходима в образовательных программах не только магистратуры и аспирантуры, но и специалитета и бакалавриата [3, с. 59-66]. ЖЖесткая направленность образовательной программы на профессиональный стандарт может привести к выпуску узкоспециализированных специалистов и, соответственно, к усилению структурной безработицы. Подчер-

\section{Baikal Research Journal}

электронный научный журнал Байкальского государственного университета 
кивается, что профессиональные стандарты включают ограниченный, жестко регламентированный перечень профессий, в то время как в современных видах профессиональной деятельности исчезает ранее преобладавшая профессиональная замкнутость [4; 2]. Можно отметить единодушие исследователей в том, что профессиональные стандарты ориентированы на текущие потребности работодателей в квалификации кадров в сложившихся технологических условиях, которые быстро меняются. Таким образом, полученные в вузе компетенции быстро устаревают и выпускник должен будет «доучиваться» либо в системе дополнительного профессионального образования, либо на рабочем месте, причем это имеет особое значение для отраслей хозяйства, отстающих в уровне технологического развития. В таких условиях вузы должны, прежде всего, закладывать базовые компетенции, позволяющие будущему специалисту адаптироваться к меняющимся требованиям рынка и учиться в течение всей трудовой жизни, а фундаментальная подготовка будущего специалиста-профессионала должна работать не на потребности сегодняшнего дня, а на перспективу [4-11].

Необходимо отметить, что принципиальная проблема, а именно невозможность формирования ФГОС только на основе ПС, фактически решена: ФГОС ВО $3++$ содержит только описание универсальных и общепрофессиональных компетенций, которые как раз и соответствуют фундаментальной университетской подготовке. Профессиональные компетенции в соответствии с профессиональными стандартами должны формулироваться Федеральными учебно-методическими объединениями (ФУМО) при разработке примерных основных образовательных программ (ПООП) и вузами при разработке основных профессиональных образовательных программ (ОПОП).

Одна из основных проблем методического характера, вызвавших широкое обсуждение - это проблема сопряжения ФГОС и профессиональных стандартов (ПС), разрабатываемых в разной терминологии. Проблемы сопоставимости отмечают Н. С. Макарова, Д. О. Виноходов, М. В. Рутто, а также П. Н. Новиков, О. Ф. Селиверстова, О. Ф. Новикова и другие авторы: в образовательных стандартах третьего поколения под видом профессиональной деятельности понимается тип деятельности: научно-исследовательский, производственно-технологический и т.п., а в профессиональных стандартах термин «вид профессиональной деятельности» соответствует обобщенным трудовым функциям $[10 ; 12-14]$. Кроме того, в профессиональных стандартах раскрывается деятельность, для чего используются термины «вид профессиональной деятельности», «обобщенные трудовые функции», «трудовые функции», «трудовые действия». В образовательных стандартах приводятся характеристики выпускника, который может осуществлять профессиональную деятельность, и в качестве ключевого используется термин «компетенция». Формулировки требований ФГОС и профессиональных стандартов могут формально не совпадать, что требует глубокого анализа их содержания $[15 ; 16]$.

Предлагаются варианты решения проблем сопоставимости ФГОС и ПС, в том числе использование системного подхода на базе современных информационных технологий $[17$, с. 15-17], метод проектирования ОПОП на основе сопряжения и фундирования профессиональных, образовательных стандартов и Национальной рамки квалификаций [18, с. 65-73], метод функциональных карт видов профессиональной деятельности [19, с. $17-18]$, разработка и введение рамки соответствия разделов ФГОС и ПС [14, с. 9-10]. Для решения вопросов, возникающих в результате выявления неполного соответствия профессиональных компетенций ФГОС трудовым функциям ПС, как правило, предлагается устранять противоречия такого рода через развитие программ дополнительного профессионального образования [18, с. $65-73 ; 20$, с. $35-37]$.

\section{Baikal Research Journal}

электронный научный журнал Байкальского государственного университета 
В качестве важной проблемы, возникающей при разработке ФГОС на основе ПС, отмечается неполный охват профессиональными стандартами различных областей профессиональной деятельности, а также недостатки некоторых профессиональных стандартов. Кроме того, ставится проблема быстрого устаревания утвержденных ПС по ряду видов профессиональной деятельности [3; 7; 20-22].

Несмотря на обоснованность описанных дискуссионных моментов, проблема перехода к ФГОС ВО 3++ переходит в организационную плоскость. По ряду направлений подготовки бакалавриата и магистратуры ФГОС ВО 3++ уже утверждены. Приказы об утверждении ФГОС ВО 3++ вступают в силу 30 декабря 2017 г. В соответствии с этими приказами прием абитуриентов в вузы по образовательным программам, разработанным в соответствии со старыми стандартами (ФГОС ВО) заканчивается 31 декабря 2018 г. Соответственно, образовательные организации высшего образования могут осуществлять прием на обучение по данным направлениям подготовки в $2018 / 2019$ учебном году как по старому ФГОС ВО, так и по новому ФГОС ВО $3++$. Но в $2019 / 2020$ учебном году осуществлять прием можно будет только по новым ФГОС ВО 3++. Значит, организационная и методическая работа по разработке новых образовательных программ с учетом профессиональных стандартов сейчас является исключительно актуальной задачей для отечественных вузов.

Устанавливая перечень универсальных и общепрофессиональных компетенций, ФГОС ВО 3++ указывает, что формирование профессиональных компетенций осуществляется на основе профессиональных стандартов, соответствующих профессиональной деятельности выпускников (при наличии), а также, при необходимости, на основе анализа требований к профессиональным компетенциям, предъявляемым к выпускникам на рынке труда, обобщения отечественного и зарубежного опыта, проведения консультаций с ведущими работодателями, объединениями работодателе отрасли, в которой востребованы выпускники, иных источников. Профессиональные компетенции могут быть установлены ПООП в качестве обязательных и (или) рекомендуемых.

Таким образом, при проектировании ОПОП в вузе на основе ФГОС $3++$ принципиальным является наличие профессиональных стандартов и ПООП.

Рассмотрим степень готовности к переходу на ФГОС ВО 3++ на примере крупного вуза - Байкальского государственного университета (ФГБОУ ВО «БГУ»). Результаты анализа наличия профессиональных стандартов, ФГОС ВО 3++ и проектов ФГОС ВО 3++, а также примерных основных образовательных программ по направлениям бакалавриата, магистратуры и специальностям, реализуемым в БГУ, приведены в табл. 1 .

Таблица 1

Результаты анализа наличия профессиональных стандартов, утвержденных ФГОС $3++$ и их проектов, а также примерных

основных профессиональных образовательных программ по направлениям бакалавриата, магистратуры и специальностям, реализуелым в ФГБОУ ВО «БГУ» (набор 2017/2018 г2.)

\begin{tabular}{|l|r|r|r|r|r|}
\hline \multirow{2}{*}{ Уровни подготовки } & \multirow{2}{*}{$\begin{array}{c}\text { Количество } \\
\text { программ }\end{array}$} & $\begin{array}{c}\text { Число программ, } \\
\text { где есть } \\
\text { подходящие ПC }\end{array}$ & $\begin{array}{l}\text { утвержден- } \\
\text { ных ФГОС } \\
\text { ВО 3++ }\end{array}$ & $\begin{array}{c}\text { Проектов } \\
\text { ФГОС ВО } \\
3++\end{array}$ & $\begin{array}{c}\text { примерных } \\
\text { ОПОП }\end{array}$ \\
\hline Бакалавриат & 25 & 18 & 3 & 9 & 0 \\
\hline Магистратура & 28 & 21 & 2 & 7 & 0 \\
\hline Специалитет & 5 & 3 & 0 & 0 & 0 \\
\hline Итого & 58 & 42 & 5 & 16 & 0 \\
\hline
\end{tabular}

\section{Baikal Research Journal}


Все образовательные программы в зависимости от наличия ФГОС ВО 3++ и их проектов можно разделить на три группы.

Первая группа - это образовательные программы, где ФГОС ВО 3++ по направлениям подготовки уже утверждены и где проблема разработки основных профессиональных образовательных программ (ОПОП) в соответствии с требованиями профессиональных стандартов стоит наиболее остро. Для БГУ это ОПОП по направлениям подготовки Лесное дело и Журналистика (бакалавриат и магистратура), Международные отношения и Туризм (бакалавриат).

Анализ утвержденных ФГОС ВО $3++$ показывает, что переход к новым стандартам в 2018 году будет затруднен и вузы, вероятнее всего, отложат переход на новые ФГОС до 2019 г., воспользовавшись возможностью, указанной в приказе Минобрнауки РФ. Это связано с тем, что профессиональные стандарты, на которые могут быть ориентированы ОПОП по данным направлениям подготовки высшего образования, еще не приняты. Так, в утвержденном стандарте ФГОС ВО $3++$ по направлению бакалавриата Лесное дело (утвержден приказом МОН № 706 от 16.08.2017, зарегистрирован Минюстом № 47808 от 16.08.2017) приложение с перечнем рекомендованных профессиональных стандартов отсутствует. Аналогичная ситуация - по направлению бакалавриата Международные отношения: в проекте ФГОС ВО 3++ указано на отсутствие профессиональных стандартов, соответствующих профессиональной деятельности выпускников, освоивших программу бакалавриата по направлению «Международные отношения», в реестре профессиональных стандартов, а в утвержденном ФГОС ВО 3++ по данному направлению бакалавриата (утвержден приказом МОН № 555 от 15.06.2017, зарегистрирован Минюстом № 47304 от 05.07.2017.) приложение с перечнем рекомендованных профессиональных стандартов отсутствует.

В ФГОС ВО 3++ по направлению магистратуры Лесное дело (утвержден приказом МОН № 667 от 17.07.2017, зарегистрирован Минюстом № 47640 от 02.08.2017), рекомендован только профессиональный стандарт «Педагог профессионального обучения, профессионального образования и дополнительного профессионального образования». Конечно, при выборе педагогического вида деятельности этот профессиональный стандарт может быть использован, однако для других видов деятельности, предусмотренных образовательным стандартом по направлению магистратуры Лесное дело, подходящих профессиональных стандартов пока просто нет.

По некоторым направлениям подготовки ситуация с разработкой профессиональных стандартов более благополучна, что позволяет в ФГОС ВО 3++ дать обоснованные рекомендации по перечню профессиональных стандартов, на которые может быть ориентирована разрабатываемая образовательной организацией ОПОП.

Важно отметить, что проекты ФГОС ВО 3++ публикуются для широкого обсуждения, что позволяет усовершенствовать их к моменту утверждения. Кроме того, при утверждении ФГОС ВО 3++ учитываются профессиональные стандарты, разработанные после опубликования проектов ФГОС ВО $3++$. Так, в утвержденном ФГОС ВО 3++ по направлению магистратуры Журналистика (утвержден приказом МОН № 529 от 08.06.2017, зарегистрирован Минюстом № 47239 от 29.06.2017) перечень рекомендованных ПС дополнен по сравнению с проектом ФГОС ВО $3++$.

Однако процесс принятия профессиональных стандартов продолжается, появляются новые профессиональные стандарты, которые оказываются не включенными в число рекомендованных ФГОС ВО 3++. Соответственно, ФГОС разрешает образовательной организации выбор ПС не только из числа указанных в приложении к соответствующему ФГОС ВО $3++$, но и из числа иных ПС, соответствую-

\section{Baikal Research Journal}


щих профессиональной деятельности выпускников, из реестра профессиональных стандартов, размещенного на специализированном сайте Минтруда РФ (при их наличии). Так, в ФГОС ВО $3++$ по направлению бакалавриата Туризм (утвержден приказом МОН № 516 от 08.06.2017, зарегистрирован Минюстом № 47223 от 29.06.2017), рекомендован только один ПС - Экскурсовод (гид), хотя в настоящее время в реестре профессиональных стандартов есть еще по крайней мере один ПС, соответствующий профессиональной деятельности выпускников - Руководитель/управляющий гостиничного комплекса/сети гостиниц.

При включении в ФГОС ВО $3++$ перечня рекомендуемых профессиональных стандартов допускаются явные неточности. Так, в ФГОС ВО $3++$ по направлению бакалавриата Журналистика (утвержден приказом МОН № 524 от 08.06.2017, зарегистрирован Минюстом № 47219 от 29.06.2017) рекомендован, в числе прочих, профессиональный стандарт «Специалист по продвижению и распространению продукции СМИ», предусматривающий не соответствующие данному направлению подготовки наименования должности, профессии, специальности: маркетинг, менеджмент, коммерция. Возможно, в ФГОС ВО 3++ будут внесены корректировки. Однако сложившаяся ситуация свидетельствует о недостаточно высоком качестве утвержденных ФГОС ВО $3++$, что, безусловно, осложнит образовательным организациям работу по их внедрению.

Обобщенная характеристика утвержденных ФГОС ВО 3++ по направлениям бакалавриата и магистратуры, реализуемым в ФГБОУ ВО «БГУ», представлена в табл. 2.

Таблица 2

Характеристика утвержденных ФГОС ВО 3++ по направлениял бакалавриата и магистратуры, реализуемыл в ФГБОУ ВО «БГУ»

\begin{tabular}{|c|c|c|}
\hline $\begin{array}{l}\text { Направление } \\
\text { подготовки }\end{array}$ & Рекомендованные ПС & Комментарии \\
\hline $\begin{array}{l}09.03 .03 \\
\text { Прикладная } \\
\text { информатика }\end{array}$ & $\begin{array}{l}\text { Программист } \\
\text { Специалист по информационным } \\
\text { системам } \\
\text { Руководитель проектов в области IT } \\
\text { Руководитель разработки программ- } \\
\text { ного обеспечения } \\
\text { Системный аналитик }\end{array}$ & $\begin{array}{l}\text { В состав рекомендованных ПС внесе- } \\
\text { ны изменения, по сравнению с про- } \\
\text { ектом ФГОС 3++: убрали ПС Специ- } \\
\text { алист по НИОКР и Специалист по } \\
\text { организации и управлению НИОКР. } \\
\text { Есть и появляются другие подходя- } \\
\text { щие ПС: } \\
\text { Администратор баз данных } \\
\text { Специалист по информационным } \\
\text { ресурсам } \\
\text { Специалист по интеграции приклад- } \\
\text { ных решений и др. }\end{array}$ \\
\hline $\begin{array}{l}35.03 .01 \text { Лес- } \\
\text { ное дело }\end{array}$ & Нет & $\begin{array}{l}\text { ПС, соответствующих специфике на- } \\
\text { правления подготовки, нет в реестре }\end{array}$ \\
\hline $\begin{array}{l}\text { 41.03.05 Меж- } \\
\text { дународные } \\
\text { отношения }\end{array}$ & Нет & $\begin{array}{l}\text { ПС, соответствующих специфике на- } \\
\text { правления подготовки, нет в реестре }\end{array}$ \\
\hline $\begin{array}{l}42.03 .02 \text { Жур- } \\
\text { налистика }\end{array}$ & $\begin{array}{l}\text { Специалист по продвижению и рас- } \\
\text { пространению продукции СМИ } \\
\text { Специалист по информационным } \\
\text { ресурсам } \\
\text { Корреспондент СМИ } \\
\text { Ведущий телевизионной программы } \\
\text { Специалист по производству про- } \\
\text { дукции телерадиовещательных СМИ } \\
\text { Редактор СМИ } \\
\text { Режиссер СМИ } \\
\text { Фотограф } \\
\text { Графический дизайнер } \\
\end{array}$ & $\begin{array}{l}\text { Рекомендован, в числе прочих, про- } \\
\text { фессиональный стандарт «Специалист } \\
\text { по продвижению и распространению } \\
\text { продукции СМИ», предусматрива- } \\
\text { ющий не соответствующие данному } \\
\text { направлению подготовки наименова- } \\
\text { ния должности, профессии, специ- } \\
\text { альности: маркетинг, менеджмент, } \\
\text { коммерция }\end{array}$ \\
\hline
\end{tabular}

\section{Baikal Research Journal}

электронный научный журнал Байкальского государственного университета 
Окончание табл. 2

\begin{tabular}{|c|c|c|}
\hline $\begin{array}{c}\text { Направление } \\
\text { подготовки }\end{array}$ & Рекомендованные ПС & Комментарии \\
\hline $\begin{array}{l}\text { 43.03.02 Ту- } \\
\text { ризм }\end{array}$ & Экскурсовод (гид) & $\begin{array}{l}\text { Есть еще ПС, подходящий по квали- } \\
\text { фикационным требованиям: } \\
\text { Руководитель/управляющий гости- } \\
\text { ничного комплекса/сети гостиниц }\end{array}$ \\
\hline $\begin{array}{l}35.04 .01 \text { Лес- } \\
\text { ное дело }\end{array}$ & $\begin{array}{l}\text { Педагог профессионального обуче- } \\
\text { ния, профессионального образова- } \\
\text { ния и дополнительного профессио- } \\
\text { нального образования }\end{array}$ & $\begin{array}{l}\text { ПС, соответствующих специфике на- } \\
\text { правления подготовки, нет в реестре }\end{array}$ \\
\hline $\begin{array}{l}\text { 42.04.02 Жур- } \\
\text { налистика }\end{array}$ & $\begin{array}{l}\text { Педагог профессионального обуче- } \\
\text { ния, профессионального образова- } \\
\text { ния и дополнительного профессио- } \\
\text { нального образования } \\
\text { Специалист по производству про- } \\
\text { дукции сетевых изданий и инфор- } \\
\text { мационных агентств } \\
\text { Ведущий телевизионной программы } \\
\text { Специалист по производству про- } \\
\text { дукции телерадиовещательных СМИ } \\
\text { Специалист по производству про- } \\
\text { дукции печатных СМИ } \\
\text { Графический дизайнер } \\
\text { Редактор СМИ }\end{array}$ & $\begin{array}{l}\text { По сравнению с проектом ФГОС } 3++, \\
\text { добавлен ПС Редактор СМИ }\end{array}$ \\
\hline
\end{tabular}

Вторая группа образовательных программ - это ОПОП по направлениям подготовки, где ФГОС ВО 3++ еще не утверждены, но опубликованы проекты ФГОС ВО $3++$. Для БГУ это ОПОП по направлениям подготовки/специальностям Прикладная информатика, Землеустройство и кадастры, Социальная работа, Лингвистика (бакалавриат, магистратура) и Психология (бакалавриат, магистратура и специалитет). Особый интерес представляет анализ качества имеющихся проектов ФГОС ВО $3++$.

Проекты ФГОС ВО 3++ по направлениям бакалавриата и магистратуры Прикладная информатика характеризуются высоким качеством. По данным направлениям подготовки есть достаточное количество утвержденных профессиональных стандартов, они проанализированы разработчиками проектов ФГОС и корректно рекомендованы в соответствии с требуемыми уровнями подготовки (бакалавриат и магистратура). В то же время, появляются новые подходящие профессиональные стандарты (например, Специалист по интеграции прикладных решений). При утверждении ФГОС ВО 3++ по данным направлениям подготовки будет, скорее всего, уточнен в плане перечня рекомендуемых профессиональных стандартов.

В проекте ФГОС ВО 3++ по направлению Лингвистика (бакалавриат и магистратура) предложены только профессиональные стандарты по педагогике ввиду отсутствия в реестре профессиональных стандартов по другим видам деятельности, предусмотренным проектом образовательных стандартов.

Можно с уверенностью прогнозировать, что процесс принятия новых профессиональных стандартов будет продолжаться в течение длительного времени, поэтому необходимо создание механизма периодического обновления ФГОС ВО $3++$ в части перечня рекомендуемых профессиональных стандартов.

Анализ проектов ФГОС ВО 3++ по направлению бакалавриата и магистратуры Землеустройство и кадастры в части перечня рекомендованных профессиональных стандартов выявил наибольшее число несоответствий. Так, в проекте

\section{Baikal Research Journal}


ФГОС ВО 3++ по направлению бакалавриата Землеустройство и кадастры необоснованно рекомендован профессиональный стандарт «Специалист по управлению персоналом», рекомендован профессиональный стандарт «Специалист в сфере инженерно-геодезических изысканий», отсутствующий в реестре профессиональных стандартов. В этом проекте рекомендованы профессиональные стандарты, предусматривающие не соответствующие направлению подготовки Землеустройство и кадастры наименования должности, профессии, специальности. Это профессиональный стандарт «Градостроитель» (наименования должности, профессии, специальности: архитектор, проектировщики-градостроители, эколог градостроительства, социолог градостроительства, экономист градостроительства) и профессиональный стандарт «Специалист по качеству продукции» (наименования должности, профессии, специальности: инженеры-механики, управление качеством, стандартизация и сертификация).

Проект ФГОС 3++ по направлению магистратуры Землеустройство и кадастры характеризуется аналогичными несоответствиями. Так же, как и в проекте ФГОС ВО 3++ по направлению бакалавриата, рекомендован профессиональный стандарт «Специалист в сфере инженерно-геодезических изысканий», отсутствующий в реестре. Рекомендованы профессиональные стандарты, предусматривающие не соответствующие данному направлению подготовки наименования должности, профессии, специальности: «Градостроитель» (архитектор, проектировщики-градостороитель, эколог градостроительства, социолог градостроительства, экономист градостроительства), «Специалист по качеству продукции» (инженеры-механики, управление качеством, стандартизация и сертификация), «Специалист по логистике в сфере обращения с отходами» (менеджмент, логистика).

Трудности формирования образовательных программ на основе профессиональных стандартов в сфере землеустройства и кадастров в значительной степени определяются динамичными изменениями в законодательстве в данной сфере. Так, С. А. Мамонтова и О. П. Колпакова отмечают, что профессиональный стандарт "Специалист в сфере кадастрового учета", который на данный момент является единственным профессиональным стандартом именно в сфере землеустройства и кадастров, с введением в действие Федерального закона ФЗ № 218 «О государственной регистрации недвижимости» во многом утратил свою актуальность. Так, обобщенная трудовая функция «Осуществление государственного кадастрового учета недвижимого имущества» передана государственному регистратору, который должен иметь юридическое образование, а не образование в сфере землеустройства и кадастров. При этом проекты профессиональных стандартов «Землеустроитель» и «Кадастровый инженер» уже почти два года находятся в стадии согласования [22, с. 218-221].

Кроме того, имеются несоответствия в рекомендованных проектами ФГОС ВО $3++$ профессиональных стандартах по уровню подготовки. Так, в проекте ФГОС ВО 3++ по направлению магистратуры Землеустройство и кадастры рекомендован профессиональный стандарт «Специалист по организационному и документационному обеспечению управления организацией», в котором в качестве требуемого уровня подготовки указаны уровни СПО и бакалавриата. Рекомендация данного ПС в проекте ФГОС 3++ по уровню магистратуры ошибочна. Профессиональный стандарт «Специалист по управлению рисками», в котором в качестве требуемого уровня подготовки указаны уровни бакалавриата и магистратуры, рекомендован только в проекте ФГОС ВО $3++$ по направлению магистратуры Землеустройство и кадастры, а в проекте ФГОС ВО $3++$ по направлению бакалавриата Землеустройство и кадастры - не рекомендован.

\section{Baikal Research Journal}

электронный научный журнал Байкальского государственного университета 
Подобные несоответствия характерны и для проектов ФГОС ВО 3++ по другим направлениям подготовки. Так, в проекте ФГОС ВО 3++ по направлению бакалавриата Социальная работа ошибочно рекомендован профессиональный стандарт «Специалист по работе с семьей», в котором в качестве требуемого уровня подготовки указан уровень магистратуры. А в проекте ФГОС ВО 3++ по направлению магистратуры Социальная работа ошибочно рекомендованы профессиональный стандарт «Специалист по социальной работе», в котором в качестве требуемого уровня подготовки указан уровень бакалавриата и профессиональный стандарт «Руководитель организации социального обслуживания», в котором в качестве требуемого уровня подготовки указан уровень СПО. Данные противоречия уже описаны в научной литературе [21, с. 232-235].

Отдельно хотелось бы остановиться на рекомендованном в отдельных ФГОС ВО $3++$ и их проектах профессиональном стандарте «Педагог профессионального обучения, профессионального образования и дополнительного профессионального образования». Как в действующих ФГОС ВО, так и в утвержденных новых ФГОС ВО $3++$ и их проектах педагогический вид деятельности предусмотрен по уровням подготовки магистратуры и специалитета. Соответственно, в утвержденных ФГОС ВО 3++ магистратуры (Лесное дело, Журналистика) и специалитета (Психология служебной деятельности) обоснованно рекомендован профессиональный стандарт «Педагог профессионального обучения, профессионального образования и дополнительного профессионального образования». Во всех проектах ФГОС ВО 3++ уровня магистратуры по реализуемым в БГУ направлениям подготовки/специальностям рекомендован профессиональный стандарт «Педагог профессионального обучения, профессионального образования и дополнительного профессионального образования» (кроме направления магистратуры Прикладная информатика, где проект ФГОС ВО $3++$ по непонятным причинам не предусматривает педагогический вид деятельности).

Что касается программ бакалавриата, то в старых ФГОС ВО педагогический вид деятельности, как правило, не предусматривался (кроме программ педагогического образования). В утвержденных ФГОС ВО 3++ бакалавриата по реализуемым в БГУ направлениям педагогический вид деятельности отсутствует. В то же время в проектах ФГОС ВО 3++ по направлениям бакалавриата Лингвистика и Землеустройство и кадастры предусмотрен данный вид деятельности и, соответственно, рекомендован профессиональный стандарт «Педагог профессионального обучения, профессионального образования и дополнительного профессионального образования», а по направлению Лингвистика - еще два профстандарта: «Педагог (педагогическая деятельность в сфере дошкольного, начального общего, основного общего, среднего общего образования) (воспитатель, учитель)» и «Педагог дополнительного образования детей и взрослых» .

Если для направления Лингвистика такая ситуация вполне объяснима, то для направления Землеустройство и кадастры вызывает, по крайней мере, недоумение. Возможно, при утверждении ФГОС ВО 3++ соответствующие поправки будут внесены.

Основные проблемы, выявленные при анализе проектов ФГОС ВО 3++ по направлениям подготовки, реализуемым в БГУ, представлены в табл. 3. В целом генезис ФГОС характеризуется движением от хаотического разнообразия к разумной унификации, поэтому на наш взгляд, при утверждении ФГОС ВО $3++$ данная тенденция должна быть продолжена.

\section{Baikal Research Journal}

электронный научный журнал Байкальского государственного университета 
Основные проблелы, выявленные при анализе проектов ФГОС ВО $3++$ по направлениял подготовки, реализуелыл в ФГБОУ ВО “БГУ"

\begin{tabular}{|c|c|}
\hline Проблема & Примеры \\
\hline $\begin{array}{l}\text { Отсутствие в рее- } \\
\text { стре подходящих } \\
\text { профессиональных } \\
\text { стандартов }\end{array}$ & $\begin{array}{l}\text { В проекте ФГОС ВО 3++ по направлению Лингвистика (бакалавриат } \\
\text { и магистратура) предложены только профессиональные стандарты по } \\
\text { педагогике ввиду отсутствия в реестре профессиональных стандартов } \\
\text { по другим видам деятельности, предусмотренным проектом образова- } \\
\text { тельных стандартов }\end{array}$ \\
\hline $\begin{array}{l}\text { Рекомендация } \\
\text { профессионального } \\
\text { стандарта, отсут- } \\
\text { ствующего } \\
\text { в реестре } \\
\end{array}$ & $\begin{array}{l}\text { В проекте ФГОС ВО 3++ по направлению бакалавриата Землеустрой- } \\
\text { ство и кадастры рекомендован профессиональный стандарт «Специа- } \\
\text { лист в сфере инженерно-геодезических изысканий», отсутствующий в } \\
\text { реестре профессиональных стандартов }\end{array}$ \\
\hline $\begin{array}{l}\text { Рекомендация } \\
\text { профессиональных } \\
\text { стандартов, предус- } \\
\text { матривающего не } \\
\text { соответствующие } \\
\text { данному направ- } \\
\text { лению подготовки } \\
\text { наименования } \\
\text { должности, профес- } \\
\text { сии, специальности }\end{array}$ & $\begin{array}{l}\text { В проекте ФГОС ВО 3++ по направлению бакалавриата Землеу- } \\
\text { стройство и кадастры рекомендованы профессиональные стандарты, } \\
\text { предусматривающие не соответствующие направлению подготовки } \\
\text { Землеустройство и кадастры наименования должности, профессии, } \\
\text { специальности. Это профессиональный стандарт «Градостроитель» } \\
\text { (наименования должности, профессии, специальности: архитектор, } \\
\text { проектировщики-градостроители, эколог градостроительства, социолог } \\
\text { градостроительства, экономист градостроительства) и профессиональ- } \\
\text { ный стандарт «Специалист по качеству продукции» (наименования } \\
\text { должности, профессии, специальности: инженеры-механики, управле- } \\
\text { ние качеством, стандартизация и сертификация) }\end{array}$ \\
\hline $\begin{array}{l}\text { Несоответствие } \\
\text { уровней подготовки } \\
\text { в рекомендованных } \\
\text { проектами ФГОС } \\
\text { ВО 3++ професси- } \\
\text { ональных стандар- } \\
\text { тах }\end{array}$ & $\begin{array}{l}\text { В проекте ФГОС ВО 3++ по направлению магистратуры Землеустрой- } \\
\text { ство и кадастры рекомендован профессиональный стандарт «Специ- } \\
\text { алист по организационному и документационному обеспечению } \\
\text { управления организацией», в котором в качестве требуемого уровня } \\
\text { подготовки указаны уровни СПО и бакалавриата. } \\
\text { В проекте ФГОС ВО 3++ по направлению бакалавриата Социальная } \\
\text { работа ошибочно рекомендован профессиональный стандарт «Специ- } \\
\text { алист по работе с семьей», в котором в качестве требуемого уровня } \\
\text { подготовки указан уровень магистратуры. } \\
\text { В проекте ФГоС ВО } 3++ \text { по направлению магистратуры Социальная } \\
\text { работа ошибочно рекомендованы профессиональный стандарт «Специ- } \\
\text { алист по социальной работе», в котором в качестве требуемого уровня } \\
\text { подготовки указан уровень бакалавриата и профессиональный стан- } \\
\text { дарт «Руководитель организации социального обслуживания», в кото- } \\
\text { ром в качестве требуемого уровня подготовки указан уровень СПО }\end{array}$ \\
\hline
\end{tabular}

Третья группа - это ОПОП, по направлениям которых ФГОС ВО $3++$ не утверждены и отсутствуют проекты ФГОС ВО $3++$. К этой группе относится наибольшее число образовательных программ в университете, реализуемых в рамках востребованных абитуриентами и работодателями направлений подготовки «Экономика», «Менеджмент» и «Юриспруденция». В то же время, для многих ОПОП утверждены и имеются в реестре профессиональные стандарты, соответствующие областям профессиональной деятельности выпускников. Соответственно, уже сейчас необходима серьезная работа по изучению и анализу содержания этих профессиональных стандартов специалистами профильных кафедр. Опыт такой работы уже описан в научной литературе [23, с. 186-187].

Контент-анализ наличия профессиональных стандартов, соответствующих реализуемым в университете ОПОП, показал, что ситуация в значительной степени дифференцирована.

По направлению бакалавриата «Экономика» в БГУ реализуется 8 образовательных программ (набор 2016/2017 г.). Максимальное количество профессио-

\section{Baikal Research Journal}


нальных стандартов, соответствующих образовательной программе, характерно для программы «Финансы и кредит» - 21 профессиональный стандарт. Профстандарты, соответствующие данной ОПОП, исключительно разнообразны и специализированы. Наибольшее количество профессиональных стандартов (11) разработано в сфере банковской деятельности: Специалист по микрофинансовым операциям, Специалист рынка ценных бумаг, Специалист по операциям на межбанковском рынке, Специалист по потребительскому кредитованию, Специалист казначейства банка, Специалист по ипотечному кредитованию, Специалист по корпоративному кредитованию, Специалист по платежным услугам, Специалист по кредитному брокериджу, Специалист по работе с залогами, Специалист по дистанционному банковскому обслуживанию. Кроме того, ОПОП «Финансы и кредит» может быть ориентирована на профессиональные стандарты в области финансовой деятельности (Специалист по финансовому консультированию, Специалист оценочной деятельности, Специалист по лизинговой деятельности) и страхования (Специалист по страхованию, Страховой брокер, Специалист по управлению рисками, Актуарий). Ряд профессиональных стандартов (Специалист по организации и установлению выплат социального характера, Специалист по организации назначения и выплаты пенсии, Специалист по организации администрирования страховых взносов, Специалист по организации персонифицированного учета пенсионных прав застрахованных лиц) могут быть рекомендованы как для ОПОП «Финансы и кредит», так и для других образовательных программ («Бухгалтерский учет», «Социальная работа» и др.).

По направлению магистратуры «Финансы и финансовые институты» найдено 18 профессиональных стандартов.

Профстандарты, относящиеся к финансовой деятельности, лаконичны, содержат ограниченное количество трудовых функций. Соответственно, возможна ориентация данной образовательной программы на множество профессиональных стандартов одновременно (фактически, знания и навыки в рамках одного профессионального стандарта формируются при изучении профессионального модуля или 1-2 дисциплин). Такое решение целесообразно, так как ограничение количества профессиональных стандартов при определении направленности ОПОП снизит конкурентоспособность выпускников на рынке труда.

Еще одна образовательная программа бакалавриата по направлению Экономика, в достаточно полной мере обеспеченная профессиональными стандартами, - это «Бухгалтерский и налоговый учет» (11 подходящих профессиональных стандартов). Это специализированные профессиональные стандарты (Бухгалтер, Специалист по внутреннему контролю (внутренний контролер), Внутренний аудитор, Аудитор), а также профессиональные стандарты, предусматривающие возможность обучения по другим образовательным программам. По программе магистратуры «Бухгалтерский учет, налогообложение, анализ и аудит» (направление Экономика) найдено 9 профессиональных стандартов. По направлению магистратуры «Государственный аудит, контроль и безопасность» -4 профессиональных стандарта.

По образовательным программам бакалавриата «Налогообложение и контроль», «Экономика нефтегазового комплекса», «Экономика инвестиционно-строительного бизнеса и управления недвижимостью» и «Экономика предприятия и предпринимательская деятельность», программам магистратуры «Экономика фирмы, предпринимательство», «Экономика нефтегазового комплекса», «Контрактная система в сфере закупок» в реестре есть от 1 до 3 подходящих профессиональных стандартов.

\section{Baikal Research Journal}

электронный научный журнал Байкальского государственного университета 
По программам бакалавриата «Мировая экономика» и «Экономика торговли и ресторанный бизнес» и программе магистратуры «Мировая экономика и международный бизнес» профессиональные стандарты, соответствующие профессиональной деятельности выпускников, пока отсутствуют в реестре.

По направлению Менеджмент реализуются три образовательные программы бакалавриата, при этом по ОПОП «Маркетинг и рекламный бизнес» имеется 4 подходящих профстандарта, по программе «Управление малым бизнесом» один профессиональный стандарт.

По данному направлению подготовки реализуется пять магистерских программ («Стратегическое управление организацией», «Маркетинговое управление бизнесом и продажами», «Контроллинг и управление затратами», «Управление туристским и гостиничным бизнесом», «Управление градостроительной деятельностью и экономика развития территорий»), по которым в реестре в наличии от 1 до 4 профессиональных стандартов:

Нет в реестре профессиональных стандартов по направлению подготовки бакалавриата и магистратуры «Государственное и муниципальное управление».

По направлению бакалавриата «Бизнес-информатика» профессиональных стандартов, на которые может быть ориентирована ОПОП, три, по направлению бакалавриата «Торговое дело» (ОПОП «Логистика и коммерция») - 6, по направлению магистратуры «Торговое дело» (ОПОП «Управление логистическими бизнес-процессами») -5 .

По направлениям бакалавриата и магистратуры «Управление персоналом» в реестре есть 2 подходящих профессиональных стандарта, в том числе «Специалист по управлению персоналом» - один из наиболее масштабных, содержащий восемь обобщенных трудовых функций. Ясно, что при проектировании ОПОП следует провести серьезную работу по выбору обобщенных трудовых функций, а в их рамках - трудовых функций, на которые будет ориентирована образовательная программа, с учетом потребностей рынка труда в регионе.

По направлению подготовки «Юриспруденция» появился только один профессиональный стандарт: «Следователь-криминалист» (уровень подготовки магистратура), соответствующий реализуемой в БГУ ОПОП «Криминалистика, судебная экспертиза и оперативно-розыскная деятельность». По востребованным абитуриентами и рынком труда магистерским программам «Гражданское право и процесс», «Уголовное право и криминология», «Уголовный процесс и прокурорский надзор", «Государственное и административное право» профессиональные стандарты не утверждены. Остается надеяться, что разработка профессиональных стандартов в сфере юриспруденции будет продолжаться достаточно быстрыми темпами.

По реализуемым в БГУ программам специалитета профессиональных стандартов, соответствующих профессиональной деятельности выпускников, очень мало. Так, по программе «Лингвистическое обеспечение межгосударственных отношений» (специальность Перевод и переводоведение) утвержден один ПС (Педагог профессионального обучения, профессионального образования и дополнительного профессионального образования), по программе «Экономико-правовое обеспечение экономической безопасности» (специальность Экономическая безопасность один ПС (Специалист по финансовому мониторингу (в сфере противодействия легализации доходов, полученных преступным путем, и финансированию терроризма). По специальностям «Таможенное дело» и «Правовое обеспечение национальной безопасности (уголовно-правовая специализация)» профессиональных стандартов, соответствующих профессиональной деятельности выпускников, в реестре нет.

\section{Baikal Research Journal}


Как видно из таблицы 1 , ни по одной из реализуемых основных профессиональных образовательных программ примерных ООП (ПООП) в настоящее время нет. Каково значение ПООП для проектирования образовательных программ? Ответ на этот вопрос можно найти в ФГОС. ФГОС ВО 3++ не содержат формулировок профессиональных компетенций, отсылая разработчиков ОПОП к примерным основным образовательным программам (ПООП) при их наличии, либо к проведению самостоятельных исследований рынка труда.

При наличии ПООП разработчики ОПОП имеют документ, содержащий сформулированные профессиональные компетенции: обязательные и (или) рекомендуемые. Если ПООП содержит обязательные профессиональные компетенции (ОПК), то они в обязательном порядке должны быть включены в ОПОП вуза. Образовательная организация вправе включить в свою ОПОП одну или несколько рекомендуемых профессиональных компетенций (РПК), если они есть в ПООП. Если ПООП определены и ОПК, и РПК, то, включив их в ОПОП, образовательная организация может избежать работы по самостоятельной формулировке профессиональных компетенций на основе ПС и исследований регионального рынка труда. Таким образом, наличие ПООП дает некую гарантию того, что включенные в ОПОП профессиональные компетенции не вызовут нареканий при прохождении процедур контрольно-надзорной деятельности, а также лицензирования и аккредитации. При отсутствии ПООП образовательная организация должна самостоятельно осуществить методически крайне сложную работу по формулированию профессиональных компетенций на основе ПС. Прямой перенос формулировок из ПС в ОПОП невозможен, при разработке ОПОП может возникнуть необходимость использования нескольких ПС или их частей (отдельных обобщенных трудовых функций или трудовых функций) $[12$, с. $7-11 ; 24$, с. $186-187]$, поэтому самостоятельная разработка ОПОП вузом при отсутствии ПООП приводит к определенным рискам.

В то же время, в ситуации, когда ПООП отсутствует, или она разработана по профилю, который не востребован в регионе, образовательная организация сталкивается с необходимостью самостоятельной формулировки профессиональных компетенций. ФГОС ВО 3++ регламентирует эту работу следующим образом:

- профессиональные компетенции формируются на основе профессиональных стандартов, соответствующих профессиональной деятельности выпускников (при их наличии);

- выбор ПС осуществляется из числа указанных в приложении к ФГОС ВО и (или) иных ПС, соответствующих профессиональной деятельности выпускников, из реестра ПС, размещенного на специализированном сайте Минтруда РФ;

- из каждого выбранного ПС может быть выбраны одна или несколько обобщенных трудовых функций (ОТФ), соответствующих профессиональной деятельности выпускников, на основе установленных ПС для данной ОТФ уровня квалификации и требований раздела «Требования к образованию и обучению», при этом ОТФ может быть выбрана частично (то есть одна или несколько из составляющих ее трудовых функций);

- при необходимости (в том числе при отсутствии ПС, соответствующих профессиональной деятельности выпускников), образовательная организация формулирует профессиональные компетенции на основе анализа требований к профессиональным компетенциям, предъявляемым к выпускникам на рынке труда, обобщения отечественного и зарубежного опыта, консультаций с ведущими работодателями, объединениями работодателей отрасли, в которой востребованы выпускники и иных источников.

Нужно отметить, что вузы активно взаимодействуют с работодателями по разработке ОПОП [24, с 186-187]. Формы такой работы многообразны. В частности,

\section{Baikal Research Journal}

электронный научный журнал Байкальского государственного университета 
в БГУ по каждому направлению подготовки (специальности) созданы и активно функционируют методические советы, включающие представителей работодателей. Именно методические советы принимают ключевые решения при проектировании и корректировке ОПОП. Однако в случае решения задачи формулировки профессиональных компетенций требования к организационным формам взаимодействия с работодателями должны быть конкретизированы. Сколько работодателей должно быть опрошено, чтобы обоснование профессиональной компетенции в ОПОП было признано репрезентативным? Ответа на этот и другие подобные вопросы пока нет. Поскольку ФГОС ВО $3++$ не содержит требований к проведению анализа требований к выпускникам на рынке труда и опросам работодателей, сформулированные таким образом компетенции могут вызвать вопросы и проблемы при прохождении контрольно-надзорных процедур.

В заключение следует отметить исключительную важность своевременной и качественной разработки ПООП по всем основным направлениям подготовки и специальностям высшего образования. Данная работа возложена на федеральные учебно-методические объединения (ФУМО). При работе по ФГОС ВО 3++ на основе ПООП для образовательной организации резко сократится область свободы (ПООП содержит не только ОПК и РПК, но и учебный план, программы дисциплин и практик и пр.). Область свободы станет даже меньше, чем при работе по государственным образовательным стандартам (ГОС), однако и риски для образовательной организации будут минимальны.

Если ФГОС ВО 3++ будут внедряться при отсутствии разработанных ПООП, то вероятность негативных последствий достаточно велика. Для вуза увеличиваются риски при прохождении контрольно-надзорных процедур. Для Минобрнауки РФ и общества в целом риски связаны с появлением по конкретному направлению подготовки множества ОПОП, разработанных вузами самостоятельно, причем с различными формулировками профессиональных компетенций. Сейчас право разработки своих образовательных стандартов (и соответственно, формулировки профессиональных компетенций) имеют только ведущие вузы страны. Рассчитывать, что все ОПОП будут разработаны качественно, очень трудно. Для обучающихся усугубятся проблемы при переводе из одной образовательной организации в другую.

Таким образом, для перехода к ФГОС ВО 3++ образовательные организации должны быть обеспечены качественными примерными образовательными программами. Вузы должны проявить активность в исследовании совокупности профессиональных стандартов, их содержания, развивать новые формы взаимодействия с работодателями и их объединениями. Наконец, необходима организация масштабного повышения квалификации преподавательского состава по переходу на ФГОС ВО 3++ на базе Минобрнауки РФ и федеральных УМО.

\section{Список использованной литературы}

1. Былков В. Г. Трансформация системы квалификаций на основе создания профессиональных стандартов / В. Г. Былков // Известия Байкальского государственного университета. - 2014. - № 1 (93). - С. 67-73.

2. Сенашенко В. С. О соотношении профессиональных стандартов и ФГОС высшего образования / В. С Сенашенко // Высшее образование в России. - 2015. - № 6. - С. 31-36.

3. Ширинкина Е. В. Образовательные и профессиональные стандарты в условиях реформирования / Е. В. Ширинкина // Экономика: вчера, сегодня, завтра. - 2016. - Т. 6, № 11. - С. 59-66.

4. Айтхожаева Е. Ж. Профессиональные стандарты и образовательные программы / Е. ж. Айтхожаева // Современное образование: проблемы взаимосвязи образовательных и профессиональных стандартов : материалы междунар. науч.-метод. конф., Томск, 2829 янв. 2016 г. - Томск : Изд-во ТУСУРа, 2016. - С. 14-15.

\section{Baikal Research Journal}

электронный научный журнал Байкальского государственного университета 
5. Мартынов В. Г. Теория производства полуфабрикатов в приложении к высшему профессиональному образованию / В. Г. Мартынов, В. Н. Кошелев, В. С. Шейнбаум // Инженерное образование. - 2012. — № 11. - С. 96-101.

6. Дедюхина Н. В. Методология оценки конкурентоспособности предпринимательских структур на основе анализа финансовых коэффициентов / Н. В. Дедюхина // Вестник государственной полярной академии. - 2011. - № 1. - С. 2-10.

7. Балаба В. И. Что первично: профессиональные или образовательные стандарты? / В. И. Балаба // Альманах мировой науки. - 2015. - № 3-2 (3). - С. 49-50.

8. Белоцерковский А. В. К вопросу о согласовании образовательных и профессиональных стандартов / А. В. Белоцерковский // Высшее образование в России. - 2015. № 6. . С. $26-31$.

9. Бородачев В. В. Особенности разработки и внедрения профессиональных стандартов в производственную и образовательную деятельность в современных условиях / В. В. Бородачев, А. А. Лапшин // Сборник трудов по проблемам дополнительного профессионального образования. - 2014. - № 26. - С. 41-49.

10. Макарова Н. С. Проектирование основных профессиональных образовательных программ высшего образования на основе профессиональных стандартов / Н. С. Макарова // Вестник Омского государственного педагогического университета. Гуманитарные исследования. - 2016. - № 1 (10). - С. 94-97.

11. Суркова Е. В. Роль профессиональных стандартов в развитии основных профессиональных образовательных программ / Е. В. Суркова // Электронное обучение в непрерывном образовании. - 2016. - № 1 (3). - С. 91-95.

12. Новиков П. Н. Профессиональные стандарты: проблемы и перспективы развития / П. Н. Новиков, О. Ф. Селиверстова, Т. Р Новикова // Вестник Федерального государственного образовательного учреждения высшего профессионального образования «Московский государственный агроинженерный университет им. В. П. Горячкина». - 2014. Вып. 1. - С. 7-11.

13. Виноходов Д. О. Применение профессиональных стандартов при разработке образовательных программ / Д. О. Виноходов, М. В. Рутто // Новые технологии оценки качества образования : сб. материалов XI форума экспертов в сфере профессионального образования / под ред. Г. Н. Мотовой. - М. : Гильдия экспертов в сфере профессионального образования, 2016. - С. 215-218.

14. Взаимное влияние профессиональных и образовательных стандартов на формирование профессиональных компетенций у выпускников вузов в области наноэлектроники и нанотехнологий / П. Е. Троян [и др.] // Современное образование: проблемы взаимосвязи образовательных и профессиональных стандартов : сб. материалов междунар. науч.-метод. конф., Томск, 28-29 янв. 2016 г. - Томск : Изд-во Томс. гос. ун-та систем упр. и радиоэлектроники, 2016. - С. 9-10.

15. Миненкова В. В. Образовательные и профессиональные стандарты в гостиничном деле / В. В. Миненкова // Курортно-рекреационный комплекс в системе регионального развития: инновационные подходы. - 2016. - № 1. - С. 39-43.

16. Каракозов С. Д. Проектирование основных образовательных программ в условиях приведения действующих ФГОС высшего образования в соответствие с профессиональными стандартами / С. Д. Каракозов, Д. А. Петров, М. В. Худжина // Преподаватель XXI век. - 2015. - T. 1, № 2. - С. 9-23.

17. Корчевская О. В. О согласовании образовательных и профессиональных стандартов / О. В. Корчевская // Современное образование: проблемы взаимосвязи образовательных и профессиональных стандартов : материалы междунар. науч.-метод. конф., Томск, 28-29 янв. 2016 г. - Томск : Изд-во Том. гос. ун-та систем упр. и радиоэлектроники, 2016. - С. 15-17.

18. Дугарова Д. Ц. Фундирование профессиональных, образовательных стандартов и НКР как условие проектирования элементов основных профессиональных образовательных программ / Д. Ц. Дугарова, С. Е. Старостина, Л. В. Черепанова // Ученые записки Забайкальского государственного университета. Серия: Профессиональное образование, теория и методика обучения. - 2016. - Т. 11, № 6. - С. 65-73.

19. Зубкова Т. П. Функциональная карта вида профессиональной деятельности как современная основа формирования компетенций ФГОС ВО / Т. П. Зубкова // Современное

\section{Baikal Research Journal}


образование: проблемы взаимосвязи образовательных и профессиональных стандартов : материалы междунар. науч.-метод. конф., Томск, 28-29 янв. 2016 г. - Томск : Изд-во Томс. гос. ун-та систем упр. и радиоэлектроники, 2016. - С. 17-18.

20. Вербицкая Н. Р. Профессиональные и образовательные стандарты: соотношение требований к современному метрологу / Н. Р. Вербицкая // Главный метролог. — 2016. № 5. - С. 35-44.

21. Чудова С. Г. Профессиональные и образовательные стандарты в области социальной работы: согласованность квалификационных требований / С. Г. Чудова // Социально-экономическая политика России при переходе на инновационный путь развития : материалы 8-й междунар. науч.-практ. конф., Барнаул, 22 июня 2016 г. / под ред. И. К. Мищенко, Т. Е. Фасенко. - Барнаул : Колмогоров И.А., 2016. - С. 232-235.

22. Мамонтова С. А. Образовательные и профессиональные стандарты в землеустройстве и кадастрах / С. А. Мамонтова, О. П. Колпакова // Наука и образование: опыт, проблемы, перспективы развития : материалы междунар. науч.-практ. конф., Красноярск, 18-20 апр. 2017 г. - Красноярск : Изд-во КГАУ, 2017. - С. 218-221.

23. Зуев А. Н. К вопросу устранения разрыва между профессиональными и образовательными стандартами / А. Н. Зуев, Н. В. Крючкова // Информационные и педагогические технологии в современном образовательном учреждении : материалы 7-й Всерос. науч.-практ. конф. - Череповец, 2016. - С. 71-73.

24. Селиверстов С. И. Образовательные и профессиональные стандарты при подготовке экономистов / С. И. Селиверстов, Т. П. Селиверстова // Современное образование: проблемы взаимосвязи образовательных и профессиональных стандартов : материалы междунар. науч.-метод. конф., Томск, 28-29 янв. 2016 г. - Томск : Изд-во Том. гос. ун-та систем упр. и радиоэлектроники, 2016. - С. 186-187.

\section{References}

1. Bylkov V. G. Transformation of qualifications system on the basis of professional standards establishment. Izvestiya Irkutskoi gosudarstvennoi ekonomicheskoi akademii = Izvestiya of Irkutsk State Economics Academy, 2014, no. 1 (93), pp. 67-73. (In Russian).

2. Senashenko V. S. On correlation between professional standards and the FSES of higher education. Vysshee obrazovanie $v$ Rossii = Higher Education in Russia, 2015, no. 6, pp. 31-36. (In Russian).

3. Shirinkina E. V. Educational and professional standards in terms of reformation. Ekonomika: vchera, segodnya, zavtra = Economics: Yesterday, Today and Tomorrow, 2016, Vol. 6, no. 11, pp. 59-66. (In Russian).

4. Aitkhozhaeva E. Zh. Professional standards and educational programs. Sovremennoe obrazovanie: problemy vzaimosvyazi obrazovatel'nykh i professional'nykh standartov. Materialy mezhdunarodnoi nauchno-metodicheskoi konferentsii, Tomsk, yanvarya 2016 g. [Modern education: problems of educational and professional standards correlation. Materials of International Research Conference, January, 2016]. Tomsk State University of Control Systems and Radioelectronics Publ., 2016, pp. 14-15. (In Russian).

5. Martynov V. G., Koshelev V. N., Sheinbaum V. S. Theory of production of semi-products in terms of higher professional education. Inzhenernoe obrazovanie = Engineering Education, 2012, no. 11, pp. 96-101. (In Russian).

6. Dedyukhina N. V. Methodology for assessing competitiveness of entrepreneurial structures based on the analysis of financial ratios. Vestnik gosudarstvennoi polyarnoi akademii= Bulletin of State Polar Academy, 2011, no. 1, pp. 2-10. (In Russian).

7. Balaba V. I. What is primary: professional standards or educational? Al'manakh mirovoi nauki = Almanac of the World Science, 2015, no. 3-2 (3), pp. 49-50. (In Russian).

8. Belotserkovsky A. V. On the issue of accordance of educational and professional standards. Vysshee obrazovanie $v$ Rossii = Higher Education in Russia, 2015, no. 6, pp. 26-31. (In Russian).

9. Borodachev V. V., Lapshin A. A. Features of development and implementation of professional standards in production and educational activities in modern terms. Sbornik trudov po problemam dopolnitel'nogo professional'nogo obrazovaniya = The collection of works on the problems of additional professional education, 2014, no. 26, pp. 41-49. (In Russian).

\section{Baikal Research Journal}


10. Makarova N. S. Designing basic professional educational programs of higher education on the basis of professional standards. Vestnik Omskogo gosudarstvennogo pedagogicheskogo universiteta. Gumanitarnye issledovaniya = Review of Omsk State Pedagogical University. Humanitarian research, 2016, no. 1 (10), pp. 94-97. (In Russian).

11. Surkova E. V. Role of professional standards in developing basic professional educational programs. Elektronnoe obuchenie $v$ nepreryvnom obrazovanii $=$ E-learning in continuous education, 2016, no. 1 (3), pp. 91-95. (In Russian).

12. Novikov P. N., Seliverstova O. F., Novikova T. R. Professional standards: problems and development prospects. Vestnik Federal'nogo gosudarstvennogo obrazovatel'nogo uchrezhde-niya vysshego professional'nogo obrazovaniya "Moskovskii gosudar-stvennyi agroinzhenernyi universitet im. V. P. Goryachkina» =Vestnik of federal state educational institution of higher professional education "Moscow State Agroengineering University named after V. P. Goryachkin», 2014, iss. 1, pp. 7-11. (In Russian).

13. Vinokhodov D. O., Rutto M. V. Professional standards application in developing educational programs. In Motova G. N. (ed.). Novye tekhnologii otsenki kachestva obrazovaniya [New technologies for assessing education quality]. Moscow, Gil'diya ekspertov v sfere professional'nogo obrazovaniya Publ., 2016, pp. 215-218. (In Russian).

14. Troyan P. E., Gumerova G. I., Savruk E. V., Sakharov Yu. V., Chistoedova I. A. Mutual influence of professional and educational standards on developing professional competencies among university graduates in the field of nanoelectronics and nanotechnology. Sovremennoe obrazovanie: problemy vzaimosvyazi obrazovatel'nykh i professional'nykh standartov. Materialy mezhdunarodnoi nauchno-metodicheskoi konferentsii, Tomsk, yanvarya 2016 g. [Modern education: problems of educational and professional standard correlation. Materials of International Research Conference, January, 2016]. Tomsk State University of Control Systems and Radioelectronics Publ., pp. 9-10. (In Russian).

15. Minenkova V. V. Educational and professional standards in hotel business. Kurortno-rekreatsionnyi kompleks $v$ sisteme regional'nogo razvitiya: innovatsionnye podkhody $=R e-$ sort and recreational complex in the system of regional development: innovative approaches, 2016, no. 1, pp. 39-43. (In Russian).

16. Karakozov S. D., Petrov D. A., Khudzhina M. V. Developing basic educational programs in terms of bringing the existing FSES of higher education in line with professional standards. Prepodavatel' XXI vek = Teacher of the $21^{\text {th }}$ Century, 2015, vol. 1, no. 2, pp. 9-23. (In Russian).

17. Korchevskaya O. V. On agreement of educational and professional standards. Sovremennoe obrazovanie: problemy vzaimosvyazi obrazovatel'nykh i professional'nykh standartov. Materialy mezhdunarodnoi nauchno-metodicheskoi konferentsii, Tomsk, yanvarya 2016 g. [Modern education: problems of correlation of educational and professional standards. Materials of International Research Conference, Tomsk, January, 2016]. Tomsk State University of Control Systems and Radioelectronics Publ., 2016, pp. 15-17. (In Russian).

18. Dugarova D. Ts., Starostina S. E., Cherepanova L. V. Funding of professional, educational standards and the NKR as a condition for developing elements of the main professional educational programs. Uchenye zapiski Zabaikal'skogo gosudarstvennogo universiteta. Seriya: Professional'noe obrazovanie, teoriya i metodika obucheniya = Scholarly Notes of Transbaikal State University. Series: Vocational Education, Theory and Methods of Teaching, 2016, vol. 11, no. 6, pp. 65-73. (In Russian).

19. Zubkova T. P. Functional map of professional activity type as a modern basis for developing competencies of VSES HE. Sovremennoe obrazovanie: problemy vzaimosvyazi obrazovatel'nykh $i$ professional'nykh standartov. Materialy mezhdunarodnoi nauchnometodicheskoi konferentsii, Tomsk, yanvarya $2016 \mathrm{~g}$. [Modern education: problems of educational and professional standard correlation. Materials of International Research Conference, Tomsk, January, 2016]. Tomsk State University of Control Systems and Radioelectronics Publ., 2016, pp. 17-18. (In Russian).

20. Verbitskaya N. R. Professional and educational standards: correlation of requirements to a modern metrologist. Glavnyi metrolog $=$ Chief metrologist, 2016, no. 5, pp. 35-44. (In Russian).

21. Chudova S. G. Professional and educational standards in the field of social work: accordance of qualification requirements. In Mishchenko I. K., Fasenko T. E. Sotsial'no-

\section{Baikal Research Journal}


ekonomicheskaya politika Rossii pri perekhode na innovatsionnyi put' razvitiya. Materialy mezhdunarodnoi nauchno-metodicheskoi konferentsii, Barnaul, iyunya 2016 g. [Socio-economic policy of Russia in transition to innovative development path. Materials of International Research Conference, Barnaul, June, 2016]. Barnaul, Kolmogorov I.A. Publ., 2016, pp. 232235. (In Russian).

22. Mamontova S. A., Kolpakova O. P. Educational and professional standards in land management and cadastres. Nauka i obrazovanie: opyt, problemy, perspektivy razvitiya. Materialy mezhdunarodnoi nauchno-metodicheskoi konferentsii, Krasnoyarsk, aprelya 2017 g. [Science and education: experience, problems, development prospects. Materials of International Research Conference, Krasnoyarsk, April, 2017]. Krasnoyarsk state agrarian university Publ., 2017, pp. 218-221. (In Russian).

23. Zuev A. N., Kryuchkova N. V. On the issue of removing a break between professional and educational standards. Informatsionnye $i$ pedagogicheskie tekhnologii $v$ sovremennom obrazovatel'nom uchrezhdenii. Materialy mezhdunarodnoi nauchno-metodicheskoi konferentsii, Cherepovets $2016 \mathrm{~g}$. [Information and pedagogical technologies in modern educational institution. Materials of International Research Conference, Cherepovets, 2016]. Cherepovets, 2016, pp. 71-73. (In Russian).

24. Seliverstov S. I., Seliverstova T. P. Educational and professional standards in training of economists. Sovremennoe obrazovanie: problemy vzaimosvyazi obrazovatel'nykh $i$ professional'nykh standartov. Materialy mezhdunarodnoi nauchno-metodicheskoi konferentsii, Tomsk, yanvarya $2016 \mathrm{~g}$. [Modern education: problems of educational and professional standards correlation. Materials of International Research Conference, Tomsk, January, 2016]. Tomsk State University of Control Systems and Radioelectronics Publ., 2016, pp. 186-187. (In Russian).

\section{Информация об авторах}

Озерникова Татьяна Георгиевна - доктор экономических наук, профессор, кафедра экономики труда и управления персоналом, Байкальский государственный университет, профессор, 664003, г. Иркутск, ул. Ленина, 11, e-mail: ozernikova@mail.ru.

Пензина Ольга Николаевна - заместитель начальника управления «Центральная приемная комиссия» БГУ, студент магистратуры БГУ, 664003, г. Иркутск, ул. Ленина, 11, e-mail: penzinaon@bgu.ru

\section{Authors}

Tatiana G. Ozernikova - Doctor habil. in Economics, Professor, Chair of Labor Economics and Human Recourses Management, Baikal State University, 11 Lenin St., 664003, Irkutsk, e-mail: ozernikova@mail.ru.

Olga N. Penzina - Deputy Head of Department «Central Admission Board» of Baikal State University, Master Degree Student, Baikal State University, 11 Lenin St., 664003, Irkutsk, e-mail: penzinaon@bgu.ru

\section{Для цитирования}

Озерникова Т. Г. О применении профессиональных стандартов при проектировании образовательных программ в вузе / Т. Г. Озерникова, О. Н. Пензина // Baikal Research Journal. - 2018. — T. 9, № 1. - DOI : 10.17150/2411-6262.2018.9(1).11.

\section{For Citation}

Ozernikova T. G., Penzina O. N. On Application of Professional Standards in Developing University Educational Programs. Baikal Research Journal, 2018, vol. 9, no. 1. DOI: 10.17150/2411-6262.2018.9(1).11. (In Russian).

\section{Baikal Research Journal}

